\title{
MEDICINA Y MINERÍA EN EL ALMADÉN DEL SIGLO XVIII. JOSEPH PARÉS Y FRANQUÉS (MATARÓ, 1720-ALMADÉN, 1798)
}

RAFAEL GIL BAUTISTA

Fecha de recepción: marzo 2008

Fecha de aceptación: diciembre 2008

\section{1.- INTRODUCCIÓN}

A lo largo de las siguientes páginas vamos a acercarnos a la figura del ilustrado D. José Parés y Franqués (1720-1798), médico de cuna catalana que vivirá media vida destinado y dedicado a ejercer su labor nosológica en las Reales Minas de Almadén del Azogue.

La aproximación a este personaje comenzará por indagar sobre su origen familiar en Mataró: alguna breve pincelada sobre su abuelo paterno, médico como luego lo sería él; su padre familiar del Santo Oficio; y el nacimiento de sus hermanas y hermano. Proseguirá con las circunstancias que rodean a esta ciudad mediterránea tras el advenimiento de la nueva dinastía borbónica y su nueva política centralizadora, así como la formación de nuestro personaje en la universidad Sertoriana de Huesca, donde alcanzará los honores de bachiller primero e intentará ingresar como profesor después.

Tras un periplo por tierras castellanas y andaluzas (su propio testimonio nos lo sitúa en Madrid, Córdoba y distintas poblaciones manchegas del Campo de Calatrava: Granátula, Puertollano y Almodóvar del Campo donde está registrado en el interrogatorio del Catastro de Ensenada, 1751), aparecerá en 1759 en Almadén. Esta será la ocasión para conocer por un lado el entramado familiar que allí forjará: su matrimonio con Juana Ramiro Arcayos le permitirá emparentar con una de las familias de mayor prestigio social; y por otro, para aproximarnos al contexto social e histórico de la villa minera en la segunda mitad del s. XVIII. Le dedicaremos unas líneas a sus quehaceres y responsabilidades municipales, pues allí ejercerá a lo largo de quince años de regi- 
dor, de procurador síndico, de mayordomo de la iglesia parroquial o de la cofradía del Santísimo.

Además de conocer las importantes construcciones de este periodo: hospital de mineros de San Rafael, Plaza de Toros circunscrita por viviendas para trabajadores, la Cárcel Nueva o la Academia de Minas. Será también momento para apuntar algunas reflexiones sobre la idiosincrasia tan peculiar de los almadenenses, acostumbrados a las penalidades que marca su actividad minera, o a los rigores de las cambiantes condiciones climáticas, pero que no pierden ocasión de celebrar sus anuales festejos taurinos.

Los últimos apartados versarán sobre los aspectos profesionales de nuestro galeno y su enorme legado intelectual. Las condiciones sanitarias en las que tienen que desarrollar su labor los mineros, con especial atención al hidrargirismo y al recinto hospitalario, entendido tanto como lugar de prácticas médicas para personal especializado (médico, cirujano, boticario, enfermeros), como espacio para recuperar y tratar a los azogados y sus familias. Finalmente, a falta de localizar la obra Apologema de la mas verosimil medicina (c. 1765), revisaremos sus aportaciones y observaciones en tres magníficos manuscritos en los que deja constancia sobre su dilatada experiencia en aquellos recintos mercuriales: Apología (1777), Catástrofe Morbosa (1778) y la Descripción histórico-physico-medico-mineralogico-mercurial de las Reales Minas de Azogue de la Villa (1785).

\section{2.-EL ENTORNO PRIVADO. SU TRAYECTORIA VITAL}

\section{1.- Su cuna catalana}

Para adentrarnos en la personalidad de tan ilustre doctor hay que indagar en sus raíces vitales. A través del archivo parroquial de Santa María de Mataró ${ }^{1}$, hemos podido rastrear esos orígenes familiares. Sus padres, Joseph Parés Adroguer y María Franqués Picas, contrajeron matrimonio en septiembre de 1719. Se da la circunstancia de que el abuelo paterno, que en el momento de la ceremonia nupcial había fallecido, se llamaba Salvador y se le menciona como magnífico doctor en medicina. De ahí que cuando el día 29 de agosto de 1720 reciba las aguas bautismales se le nombre como Salvador Joseph Joan Magí Antoni Pere, hijo legítimo de Joseph Parés Adroguer y María Parés Franqués (quien toma el apellido del marido). Si nos atenemos a las fechas de matrimonio y nacimiento de Joseph, podemos deducir que es el primogénito, por tanto el hereu ${ }^{2}$ de la familia. De su hermano Eloy Antoni Félix Joseph Simplici, nacido

1. En el Museu Arxiu de Santa María de Mataró (MASMM) y gracias a la amabilidad de su archivero Nicolau Guayavens se han podido consultar los siguientes libros sacramentales: libro de matrimonios $\mathrm{n}^{\circ}$ 5 , f. 4, para la partida de matrimonio de sus padres; para su partida de nacimiento, libro de bautizos $\mathrm{n}^{\circ}$ 11, folio 337; para la de sus dos hermanos Eloy-Antoni y María- Magdalena- Josefa, sus referencias son, libro de bautizos $n^{\circ} 12$, f. 55 y 176 , respectivamente.

2. El hereu es la persona designada para recibir una herencia. En Cataluña, el hijo mayor es quien recibe todos los bienes y propiedades familiares. Su origen arranca en la Edad Media por la necesidad de evitar la 
en junio de 1722, no podemos ampliar noticia. Sin embargo a su hermana María M. Josefa, bautizada en enero de 1725, sí que la volveremos a encontrar junto a él en tierras manchegas. Les acompaña además su otra hermana, María Antonia, que contaba unos veinticinco años en $1765^{3}$. A ellas volveremos más adelante.

De otra parte, sabemos que su padre, Don Joseph Pares, era familiar del Santo Oficio del Tribunal de la Sta. Ynquisizion del Principado de Cataluña, (...) vezino y residente de la ziudad de Mataro, obispado de Barcelona. Por tanto, viendo la ocupación de su padre y abuelo es fácil pensar que se trataría de una familia acomodada, de hecho en el documento matrimonial figuran como testigos de su desposorio Joan Vila, escultor, y Jaume Esmandia, negociante en aquella ciudad textil.

\subsection{Mataró entorno a 1720}

Con el advenimiento de la nueva dinastía borbónica habrá un cambio radical en la estructura política de Cataluña. Los doce corregimientos o partidos surgidos tras la imposición de los Decretos de Nueva Planta (1716) serán las unidades territoriales con los que Felipe V uniformizará sus reinos siguiendo el modelo castellano colocando al corregidor en sustitución del antiguo veguer ${ }^{4}$.

En cuanto a su demarcación geográfica, queda recogida de la siguiente forma:

33. Mataró que cogerá del Veguerío de Barcelona, desde Montgát, hasta que encuentre el Veguerio de Girona, y el Sotsveguerio del Vallés, su Corregidor en Mataró, con un Teniente Letrado, y otro Teniente en Granollers, Cabeza del Vallés 5 .

Comprendía, por tanto, un extenso territorio que alcanzaba más de cien lugares incluidos en 77 municipios (70 de realengo y 7 de señorío). En el momento del nacimiento de Parés la ciudad contaba con unos seis mil habitantes, llegando en el censo de Floridablanca a la cifra de nueve mil seiscientos cincuenta y siete almas. En ese mismo 1787 se contarán 84 localidades, que habitarían un total de 59.140 habitantes $^{6}$.

división patrimonial y conservar las propiedades, fundamentalmente agrícolas, intactas. En Castilla existe una figura similar, el mayorazgo, institucionalizada a partir de los Reyes Católicos.

3. MASMM, en el libro 15 de Bautismos, f. 166, aparece su fecha de bautismo, el 28 de diciembre de 1740.

4. El veguer, cuyo título viene del latín vicarius (aquel que tiene una representación de una autoridad superior), era un funcionario de la corona que asumía responsabilidades judiciales y de representación en el territorio bajo su jurisdicción. A medida que el poder real se iba imponiendo a las jurisdicciones feudales, las veguerías aumentaron en número, hasta acabar instaurándose en todo el principado como demarcación territorial básica. En los siglos XVI y XVII, esta figura empezó a entrar en conflicto con las responsabilidades de los poderes municipales, donde era el batlle (alcalde) quien tenía esta potestad. Del mismo modo, las veguerías convivían con otra división territorial propia de la Generalidad (las veredas y las colectas) que ejercían competencias en materia fiscal. Las veguerías, por lo tanto, eran una herramienta de control del territorio por parte de la corona, enfrentada en muchas ocasiones con la Generalidad o con los poderes municipales.

5. Se puede consultar íntegro el texto «Nueva Planta de la Real Audiencia del Principado de Cataluña1716 (reimpressió 1775)» en: http://www.1librevell.cat/nueva-planta.

6. GuANYABEnS i CALVET, N.: «La documentació corregimental a l'arxiu históric de la ciutat de Mataró» www.raco.cat/index.php/SessioEstudisMataronins. 
Era una ciudad abierta al Mediterráneo que había concluido la construcción de un segundo recinto amurallado en el siglo XVII y que empezaba a tomar relevancia en el setecientos, cuando se estableció la Escuela Náutica. La construcción de veleros, el comercio colonial, la venta de vinos y las primeras manufacturas textiles llevarán a Mataró a una posición económica muy ventajosa durante esa centuria.

\subsection{Su formación en la universidad sertoriana de Huesca}

De aquella urbe catalana salió para hacer sus estudios en Huesca. La Facultad de Medicina que se encontró nuestro galeno era una institución provinciana creada a raíz de la fundación de la universidad en 1354, que competía tanto con la cercana de Zaragoza (de mayor prestigio y nivel académico) como con la recién creada universidad de Cervera (que a partir de 1717 sustituiría a las seis universidades catalanas suprimidas por Felipe V). Desconocemos por ahora los motivos que le impulsaron a tomar aquella decisión, pero si nos atenemos a las explicaciones del profesor J. M ${ }^{\mathrm{a}}$ Massons ${ }^{7}$, su matriculación coincidiría con la etapa de mayor afluencia de catalanes a ese recinto educativo, que él fecha entre el curso 1727-1728 y 1750 a 1759, donde alcanzaron unas cifras record. El mismo autor nos habla de las facilidades y cortas exigencias que esta universidad requería a sus alumnos como otra forma de reclamo para los estudiantes.

Sea como fuere, cabe indicar que allí, durante la etapa que él cursó su docencia, se «leían» tres cátedras: Prima, Vísperas y Tercera. La de Prima era la de categoría superior, y a ella se accedía algunas veces directamente, pero en la mayoría de los casos después de haber profesado alguna de las otras, o las dos. Las cátedras se obtenían por oposición, siendo otorgadas unas veces por votos de estudiantes, según antigua tradición, y otras por votos de los «asignados». Esta dualidad en la forma de concesión de las cátedras creó numerosos problemas.

A partir de los Estatutos de 1721 (por tanto este fue el sistema que afectó a Parés), el rey nombraba los catedráticos previo informe de la Universidad ${ }^{8}$. Con dichos Estatutos la cátedra de Prima acaba cada cuatro años: la de Vísperas cada tres, y la Tercera todos los años. Cuando un catedrático «leía» doce años, le quedaba la cátedra en propiedad hasta su jubilación, excepto en la Tercera. Los opositores para las cátedras de Prima y Vísperas tenían que estar en posesión de un grado mayor (doctor o licenciado), mientras que para la Tercera era suficiente ser bachiller y estar matriculado para la obtención de grado mayor.

Como estudiante de la Facultad pudo obtener el grado de bachiller en Artes en $1745^{9}$, por lo que poseía un perfecto conocimiento del latín (en cuya lengua se expli-

7. MASSONS i EsPlugas, J. Mª : «La Facultat de Medicina i Cirurgia d'Osca i els catalans» Gimbernat, 1998, $\mathrm{n}^{\circ} 30, \mathrm{pp} .193-205$.

8. Vid.: MenÉndez de la Puente, L. Historia de la Facultad de Medicina de la Universidad de Huesca. Caja de Ahorros y Monte de Piedad de Zaragoza, Aragón y Rioja, 1970.

9. Coinciden en esa data tanto el profesor Meléndez NAVARRo, A. Catástrofe morboso de las minas mercuriales de la villa de Almadén del Azogue (1778) de José Parés y Franqués. Edición anotada. Cuenca, Universidad de Castilla-La Mancha, 1998, p. 31; como el investigador MoNTES CID, D. Patografias y bio- 
caban las lecciones) y una formación humanística y dialéctica muy acorde con los métodos de enseñanza. El plan de estudios no era rígido, sino que cada dos años era revisado por el rector y los catedráticos. Especial importancia tuvieron las reuniones académicas, que estimulaban la formación dialéctica de los alumnos. Estas reuniones se celebraban con carácter obligatorio los domingos y jueves, actuando por turno, como «moderadores», los diferentes catedráticos.

Tras dos años más de estudio se graduó como Bachiller en Medicina. A pesar de permanecer en Huesca hasta al menos mediados de 1747, Parés no logró los grados mayores en esta universidad. Según nos informa el historiador A. Menéndez Navarro ${ }^{10}$, Parés intentó sin éxito iniciar su carrera como docente en la universidad oscense. En abril de 1747 volvió a repetir suerte, optando de nuevo sin éxito a la Cátedra Tercera de Medicina, donde se habían presentado seis aspirantes, y a la de Filosofía, con nada menos que veinte opositores ${ }^{11}$.

\section{4.- Su viaje a Francia}

Coincidiendo con ese periodo de formación va a realizar un viaje a la Francia de Luis XV. Él mismo da cuenta de su visita, mencionando muy brevemente la ciudad de Montpellier, donde describiendo algunos síntomas de enfermos dice haber visto los pulmones de algunos phisicos en el teatro de Monpellier ${ }^{12}$. Al no aportar nada más sobre esta ciudad tal vez pueda pensarse que es el deseo de querer dar un toque de calidad a sus conocimientos académicos, pues esta facultad gozaba de un gran prestigio al ser una de las más antiguas del mundo occidental.

Mayor detalle y pormenor ofrece de su visita a la región del Languedoc en 1746, al describir los tonos de distintos ríos y arroyos: Vi en una ocasión estando en el Puente

grafias médicas. Mataró 1348-1983. Editado por el autor, Mataró, 1984. En las fichas que este último recoge sobre médicos mataroníes sólo se puede leer: Joseph Parés. Bachiller en medicina por la Universidad de Huesca en 1745. Ejerció en Mataró, pero no indica la fuente de donde obtuvo la información.

10. El profesor Meléndez Navarro llega a esta conclusión después de examinar el listado aportado por MEnÉndeZ DE LA Puente, L.: «Graduados en Medicina, Cirugía y Farmacia por la Facultad de Medicina de Huesca desde el año 1566 hasta el año 1824. Relación nominal y cuadros numéricos. Breves notas relativas a algunos alumnos». IV Congreso español de Historia de la Medicina, Granada, 1973, Ediciones Actas, vol. 111, p. 180.

11. Archivo Histórico Provincial de Huesca (AHPH). Suma del Consejo de la Sertoriana Universidad y Estudio General de la ciudad de Huesca, 1746. Legajo 23/11, f. 50. Allí aparece el listado de los opuestos a las cathedras de Durando, Sexto, Decretales, Codigo, Digesto Viejo, Tercera de Medicina y de Philosofia. Unos folios más adelante (f. 59) incluso aparece la diligencia en que se cita a Parés. En la ciudad de Huesca a onze dias del mes de mayo del referido año, dicho sr. Vicerrector dio puntos para leer mañana de ocho a nueve de la mañana de oposición a la cathedra tercera de Medicina a $D^{n}$. Joseph Parés.

12. PARÉS Y FRANQUÉS, J. Catástrofe morbosa de las Minas mercuriales de la Villa de Almadén del Azogue. Historia de lo perjudicial de dichas Minas a la salud de sus operarios, y exposición de las enfermedades corporales y médico-morales de sus fosores, con la curación respectiva de ellas. Año 1778; en Archivo del Ministerio de Economía y Hacienda, sig. 489. Manuscrito 13.624, consultable en: http://www.minhac.es, ff. 253-254. 
de Santi Espiritu, en el año 1746, venir tan roja el agua del caudaloso Rhon o Rhone, que pareció sangre corriente y me satisfacieron los franceses, diciendo que acostumbraban venir de aquel modo tinturadas después de copiosas lluvias que arrastraban entre Lyon y Santi-Espiritu cantidad excesiva de tierra roja capaz de teñir toda el agua de aquel. // Vi también en el dicho año unos pequeños arroyos cerca de la gran ciudad de Puig en Velay del Languedoc, cuyas aguas verdosas dejaban inferir origen o transito por algún mineral de cobre ${ }^{13}$.

\section{DE LAS AGUAS MEDITERRÁNEAS A LA MESETA CASTELLANA}

A través del análisis de sus textos manuscritos se puede establecer la hipótesis de que fue un gran viajero, falta saber si por necesidad o por vocación. Desde 1747, en que finaliza sus estudios en tierras oscenses, hasta que finalmente recale en Almadén en 1759, va a transcurrir una docena de años donde las noticias que tenemos son breves pinceladas de su itinerario vital. Así, en su Apología ${ }^{14}$, refutando al naturalista Bowles pone como ejemplo a Granátula de Calatrava, cuando habla de las propiedades de las aguas subterráneas y deja entrever un profundo conocimiento de aquel lugar: En Granátula, villa de la provincia de la Mancha, hay un pozo de agua subaccida muy cristalina y de admirables efectos medicinales.

En muy parecidos términos cita a Puertollano y su afamada Fuente Agria. Aquí es aún más preciso, ya que explica en primera persona su estancia en aquella población:

El agua agria tan conocida de Puertollano tiene junto a sus veneros marciales un pantano formidable subterráneo de agua dulce. Lo se porque haviendose abierto años pasados una noria a alguna inmediación de la fuente agria, de cuia excavación se escaseó el caudal de la fuente se mandó agotar dicha noria para observar el movimiento de esta agua; porque toda la que se le dio a la noria era de la misma calidad que la agria de la fuente. Estando asi agotada bajé a su profundo y toda la tierra se manifestó herrumbrosa, haviendose reparado que la fuente quasi dejó de correr.

En el mismo manuscrito apologético nos menciona su visita a Madrid, de la que no aporta fecha concreta. En ella, al referir los cuidados que han de tener los espejeros y doradores al manejar los productos mercuriales, dice: vi a los que trabajan en este exercicio en Madrid quejarse muchos de las encías y dentadura. Con mayor exactitud nos lo ubica en Andalucía, aunque no podemos precisar si como residente o como viajero circunstancial. De tal manera que al comentar una plaga de langosta que azotó aquellas tierras, nos señala que:

13. PARÉS Y FRANQUÈS, J. Descripción histórico-physico-medico-mineralogico-mercurial de las Reales Minas de Azogue de la Villa de Almadén, 1785; en Archivo del Ministerio de Economía y Hacienda, sig. 488. Manuscrito 13.667, consultable en: http://www.minhac.es, ff. 62- 63.

14. PARÉS y FrAnQuÉs, J. Apología de las Reales Minas de Almadén del Azogue y de sus mineros, sobre imputarles a éstos impericia en el arte de beneficiar el mercurio, y a aquellos escasez de mineral y persuadirlas nada perjudiciales a la salud de sus operarios. (1777). Archivo del Ministerio de Economía y Hacienda, sig. 491. Manuscrito 13.834, consultable en:_http://www.minhac.es. (En adelante, Apología). Las referencias que aquí se recogen de estas localidades se ubican en el párrafo 110. 
a los lechones engordan mucho con la langosta. Yo ví en el año 1755 en Cordova, que a un jornalero que asistía a la extinción de esta plaga se le levantó una peligrosa disipela en las espaldas de llevar sobre ellas un costal de dichas langostas a un hoyo que se hizo para irlas enterrando después de muertas, pues con el peso algunas se destruyeron y su jugo levantó unas vejigas semejantes.

De todas formas, su pista más constante se puede seguir en el Campo de Calatrava, habitual semillero de personal para la plaza minera. Allí aparece en el interrogatorio del Catastro de Ensenada, en la villa de Almodóvar del Campo, noviembre de 1751, donde se recoge textualmente: (...) Un médico llamado Don Joseph Parés, a quien regulan de utilidad annual cinco mill y quinientos rs. En el tramo final de ese legajo hay una cumplida información de los efectos pertenecientes al concejo municipal. Después de especificar las dehesas, quintos, casas capitulares, pósito, cárcel pública, corral de toros, etc. aparece la asignación económica que corresponde a nuestro galeno: quattrozientos ducados, salario que le está asignado por el Real Consejo de las Ordenes, y del que goza en cada un año; los que se rel/parten entre los vezinos de esta villa para satisfazerle como ttal medico titular. ${ }^{15}$

No sabemos si mantuvo su residencia de manera continuada en esta villa calatrava hasta 1756 , pero sí que hemos podido consultar un protocolo notarial datado en la primavera de ese año en el que otorga plenos poderes a don Antonio Massip y don Salvador Pujar, residentes en Madrid, para que en su nombre consigan la impresión de un tratado médico «Apologema de la mas verosímil Medicina». En él se presenta como socio de la Real Sociedad Médica Matritense y como médico titular y vecino almodoveño, y expresa que con tal obra su deseo siempre ha perseguido que pueda aprovechar y servir a los profesores de dicha facultad o a otras personas curiosas y bien aplicadas ${ }^{16}$.

\section{4.- PARÉS EN ALMADÉN, 1759. EL ENTRAMADO FAMILIAR}

En abril de 1759, tras renunciar a su cargo de médico de la villa el doctor Juan Oltra, y procedente de Valdemoro, llega Parés a Almadén. El cabildo municipal le marca las siguientes obligaciones: un salario de tres mil rs. a cargo de las arcas públicas, permiso para cobrar un real de vellón por cada visita que efectúe a los enfermos, exceptuando a los regidores municipales y sus familias, y asistencia gratuita a los pobres enfermos de solemnidad. La duración de este contrato no marca plazo concreto;

15. AHP-CR. Legajo 653. Aquí se recoge en las páginas iniciales el interrogatorio del Catastro con sus 40 preguntas; la que nos ocupa se halla en la respuesta 32, folio 39. Más adelante, en ff. 1024 y 1025, lo referente a su salario.

16. Libro de Crónicas de la Parroquia de la Asunción de Almodóvar del Campo. Libro 4" , f. 83r-v. "Protocolo de escripturas publicas otorgadas ante Juan Perez Escobar escribano de Su Majestad publico y del numero de esta villa de Almodóvar del Campo en este presenta año de 1756". Se puede consultar el texto íntegro en el apéndice documental. Desde estas líneas el agradecimiento al profesor Gómez Vozmediano por haber puesto a nuestra disposición este documento. 
eso sí, cualquiera de las dos partes firmantes, la villa o el doctor, tendrán que advertir que dejan dicha vinculación con un margen suficiente (dos meses) para no perjudicarse. Además, se le otorga por bia de ayuda de costa para que pueda costearse y conducir a esta su homenaje y familia desde la de Valdemoro, se le socorra por una vez con mil quinientos rs. por el mayordomo de propios $^{17}$. En breve, nuestro galeno dirigirá una carta de súplica al ayuntamiento que dice textualmente: que haviendo merecido el honor de ser elegido para medico titular de esta villa, admitido este empleo y colocandose ya en ella para cumplir con dicho destino... ${ }^{18}$, se le haga llegar el contrato y la ayuda mencionada, que él había estimado en tres mil rs.

Muy pronto se va a producir el retiro del anterior doctor. En esa toma de decisión es muy posible que influyera el serio incidente que le sucedió en noviembre de $1760^{19}$, cuando fue golpeado y robado por un entibador de minas que fue a pedirle ayuda para atender de madrugada a un enfermo. Hablamos del andaluz D. Francisco López de Arévalo $^{20}$, quien tras su paso por aquella institución había mostrado sus observaciones e inquietudes por la situación que tenían que soportar los mineros. En un corto espacio de tiempo Parés permutará sus quehaceres como médico de la villa por el de minas, aunque puntualmente en años venideros, cuando en la villa se encuentren desatendidos los servicios sanitarios por ausencia o incapacidad de algún otro doctor, él comparta ambas responsabilidades.

Comienza así su andadura profesional y vital en la villa minera. De hecho ya aparece en la nómina de los ministros, oficiales y dependientes de las Reales Fábricas como médico de la Real Cárcel de Forzados. Allí se refleja el salario que goza, a el año 500 ducados, con pension de dar los 100 a su antecesor ${ }^{21}$. Hemos podido saber gracias a la relación del vecindario que mandó realizar el Gobernador y Superintendente, que en 1762 vivía en la calle Mayor de San Juan junto a sus dos hermanas (mozas solteras entonces), un criado, una criada y un acogido ${ }^{22}$. En un corto tiempo conocerá

17. En el Archivo Municipal de Almadén (en adelante AMA), el legajo 34 recoge los acuerdos municipales de 1757 a 1770 . Allí se pueden apreciar tanto la exhibición del título de doctor en medicina del valenciano D. Juan Oltra, como la carta autógrafa del mataroní.

18. AMA. Legajo 34. En el margen izquierdo del folio una diligencia del escribano nos sirve para conocer con exactitud la fecha: 21 de noviembre de 1759.

19. Archivo Histórico Nacional (en adelante AHN). Consejos, 20188, Exp. 1.

20. En la documentación de este mismo archivo se puede seguir su pista desde 1736, aunque no ejerciera la medicina de forma continuada. Sobre sus matizaciones y observaciones ver: «Lopez de Arebalo F. Lettre de ..., médicin de l'hôpital royal des forçats, dans la ville d'Almaden, à M. Thiéry, docteur-régent de la faculté de médecine de Paris (1-VI-1755)». En: Thiéry F. Observations de Physique et de Médecine faites en différens lieux de l'Espagne. Paris: Garnéry Lib; 1791. Vol. 2, p. 19-45.

21. AHN. Fondo Contemporáneo (F.C.). Minas de Almadén. Legajo 1307 (1)

22. AHN. F.C. Minas de Almadén. Legajo 1307 (2). La cita textualmente dice así: Dn. Joseph Parés, medico titular de esta villa y de la Real Carcel de Forzados, natural de la ciudad de Mataro en el Principado de Cataluña, residente en esta tres años, dos hermanas mozas solteras, un criado y una criada y un acoxido llamado Juan Garzia de Herrera, mozo soltero natural de Herrera del Duque, establezido en esta con motivo del trabajo de estas minas onze años. 
a la que sería su mujer, Juana Ramiro Arcayos. Con ella y a una edad algo avanzada, pues ya contaba más de cuarenta años, se desposa en la iglesia parroquial de N. Sra. de la Estrella, en la primavera de $1763^{23}$. Este matrimonio le va a permitir emparentar con uno de los apellidos más destacados de la sociedad minera. De origen extremeño, los Ramiro Arcayos habían presentado sus credenciales de hidalguía en 1717 para ocupar los más sobresalientes puestos de la municipalidad ${ }^{24}$. Por tanto, no nos debe extrañar que en determinadas anualidades su suegro o sus cuñados figuren como regidores municipales y con responsabilidades en el organigrama de la mina. Tal es el caso del concejal Francisco Ramiro Arcayos o de Juan Ramiro Arcayos, mayordomo de Buitrones, persona de confianza que ocupa un puesto relevante, ya que es el que controla todos los suministros y pertrechos que llegan y salen del cerco.

Tras la boda muy pronto nacerá la primogénita de la familia, Antonia. El bautizo se llevó a cabo el 16 de febrero de 1764, aunque la niña había nacido el día 11. Su nombre completo: Antonia Josepha Venita Saturnina Raphaela Juliana María de los Dolores, pero lo más llamativo será que su padrino que la tubo de pila (fue) el sr. D. Diego Luis Gijon Pacheco y San Victores, gobernador de estas Reales Minas, a quien advertí su obligazion y parentesco ${ }^{25}$. Con tres años de diferencia, en enero de 1767 , nacería su segunda hija, Luciana. El presbítero que la crismó, D. Joseph de la Resa, lo cuenta así: Una niña hija de D. Joseph Parés y Franqués, natural de la ciudad de Mataró y de $D^{a}$ Juana Ramiro y Puebla, su mujer, natural y vez ${ }^{a}$ de esta villa, pusela por nombre: Luziana, Juana, Josepha ${ }^{26}$. El padrino de nuevo vuelve a ser el señor superintendente y gobernador. A ambas muchachas volveremos para ampliar noticia.

El único hijo varón será Rafael, citado por Matilla Tascón ${ }^{27}$. Otra vez el nombre completo es muy extenso: Raphael Joseph Juan Jacinto Roque, nacido el 11 de septiembre de 1776, así aparece en los libros parroquiales de N. Sra. de la Estrella. Ahora ya no asiste al bautismo como padrino el superintendente (D. Diego había fallecido en 1773) sino $D^{a}$ Juana Ramiro Mora, por los apellidos familiar materno. Con tan sólo nueve años de edad lo encontramos en Cádiz a punto de viajar al reino del Perú. Así se desprende de la documentación que conserva el Archivo de Indias ${ }^{28}$, donde están todos los trámites requeridos antes de embarcar en el navío Aquiles: su partida de naci-

23. Archivo Diocesano de Ciudad Real (A.Dio-CR). Libro $5^{\circ}$ de matrimonios, f. 202 r.-vto. La fecha exacta es el 28 de mayo de 1763, oficiando la ceremonia frey Pedro Gijón Triviño, del hábito calatravo.

24. AMA. Legajo 32 (1). El libro 11 de los acuerdos municipales recoge la extensa documentación sobre el origen de sus privilegios y exenciones que disfrutaban en la villa de la Puebla de Alcocer y que el cabildo almadenense ratificará.

25. A.Dio-CR. Libro $12^{\circ}$ de bautismos, f. 54 vto. En este caso quien oficia la ceremonia sacramental es de nuevo don frey Pedro Gijón Triviño.

26. A.Dio-CR. Libro $12^{\circ}$ de bautismos, f. 181 vto.

27. Matilla Tascón, A. Historia de las Minas de Almadén. Vol II: desde 1646 a 1799. Minas de Almadén y Arrayanes, S.A. e Instituto de Estudios Fiscales del Ministerio de Economía y Hacienda. Madrid, 1987. Le dedica unas páginas a partir de la 316 de ese volumen.

28. Archivo General de Indias. Contratación, 5529, N.2, R.121. El texto está fechado en Cádiz el 23 de noviembre de 1785 , y figura con edad de nueve años. 


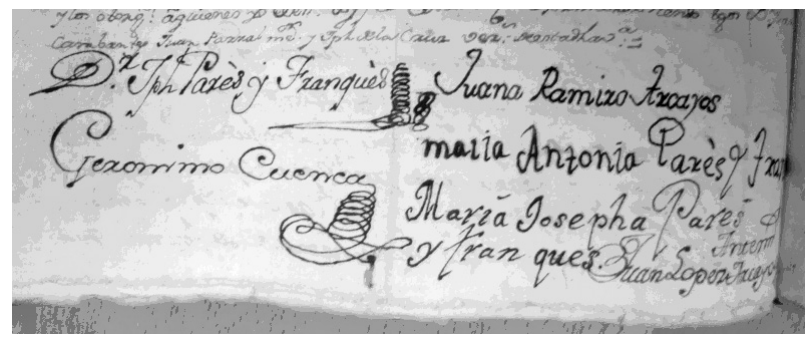

AHP-CR. Protocolos Notariales de Almadén. Legajo P-04783. Imagen con las firmas y rúbricas del médico D. José Parés y parte de su familia. Año 1765.

miento para demostrar su origen castellano, la autorización paterna donde se consiente tan arriesgada travesía y el visto bueno de D. José de Gálvez, entonces secretario del despacho de Indias. Muy probablemente esta aventura esté relacionada con la petición cursada en agosto de ese mismo año, para que se facilitase a D. José Parés una moderna colección de piedras de estas minas para remitirlas a Perú ${ }^{29}$.Será una vida intensa pero breve, pues con tal sólo veinte años, ejerciendo como oficial meritorio en la Contaduría de las Reales Fábricas, fallecerá en mayo de $1796^{30}$.

Otro hecho luctuoso, anterior a lo que estamos narrando, debió de producirse en 1765. Tras estudiar los protocolos notariales del AHP-CR, sabemos que en verano y otoño de aquel año se emitieron varios podere ${ }^{31}$ para vender bienes en su Mataró natal, en el Principado de Cataluña, lo que nos lleva a pensar que había fallecido su padre. Aquellos documentos los firmó junto a su mujer $D^{a}$ Juana Ramiro Arcayos, su cuñado D. Jerónimo Cuenca y Barea y $D^{a}$ Josepha Pares y Franqués, muger del anterior; y su hermana $D^{a}$ Maria Antonia Parés y Franqués, que confesó ser de veinte y zinco años, de estado soltera. Para evitar desplazarse hasta Cataluña, proceden a otorgar poderes ante D. Francisco Fexas y Botel y a D. Salbador Momconill, vecinos de aquella ciudad catalana para disponer vender todos los bienes muebles rayces, de aquella población o de cualquier parte, producto de esa herencia.

29. AHN. F.C. Minas Almadén. Legajo 200. La carta está firmada en San Ildefonso el 13 de agosto de 1785 y la firma y rubrica el ministro José Gálvez. Como el viaje se produce tres meses después es razonable la hipótesis de que el viaje trasatlántico para aquel muchacho de nueve años fuera una excusa para conocer tierras indianas.

30. En el AHN.F.C. Minas Almadén. Legajo 739, hay una carpetilla con la lista de los señores que contribuyeron con cuatro rs. de vellón a las misas por su alma. Lo recaudado ascendió a ochenta mrs. Este óbito se puede confirmar en el A.Dio-CR, libro de defunciones de Almadén $n^{\circ} 6$, f. 254 . No aparece la causa de la muerte, solo que recibió los santos sacramentos.

31. AHP-CR. Protocolos Notariales de Almadén. Legajo P-04783. Aquí y en diferentes fechas (19 de agosto, 9 de octubre y noviembre de 1765) firma junto a los suyos poderes para liquidar la herencia que tenían en la ciudad de Mataró. Resalta la intensa vinculación familiar con la administración minera. Su mujer es hermana del Mayordomo de Buitrones, Juan Ramiro Arcayos; su cuñado Jerónimo Cuenca era empleado en el exerzicio de maestro sobreestante de las reales obras. 
Gracias a la documentación consultada en el archivo Diocesano de Ciudad Real, sabemos que su hermana mayor, que rondaba los cuarenta años, se había desposado en la parroquial almadenense en junio de $1764^{32}$. Su marido, muy propio de la época, será hombre de cierto nivel social pues era hijo del cirujano de la Real Cárcel de Forzados, D. Lucas Cuenca, y trabajaba como empleado en la administración de los cercos mineros, en concreto como oficial de la Factoría ${ }^{33}$. Además, su hermana Antonia, que le acompañaba desde los nueve años, terminaría contrayendo nupcias en la villa manchega con D. Francisco Losada. De ella sabemos que no tuvo descendencia y que había fallecido antes que su marido, que fue enterrado en 1798 .

Ya que estamos hablando de desposorios, debemos dar cuenta de los enlaces matrimoniales de sus hijas. La mayor se casará, en febrero de 1791, con Francisco Carlos de la Garza (1757-1832) ${ }^{34}$. Este burgalés había llegado a estas tierras en 1778 entre un reducido grupo de alumnos que integrarán la primera promoción de la recién inaugurada Academia (1777), bajo la docencia de E. C. Storr. Se le asignará un salario de 12 rs. diarios para su manutención mientras se instruía en Mineralogía y Geología subterránea. En 1790, justo antes de su boda, había obtenido el título de Delineador y había participado en 1788 en el descubrimiento de las minas de carbón de piedra en Espiel, Bélmez y Peñarroya, lo que le supondrá una gratificación extra. De ese matrimonio nacerían los dos únicos nietos conocidos de Parés. Una niña, Natalia ${ }^{35}$ Rafaela Josefa de los Dolores, que vería la luz el día primero de diciembre de 1791 y que apadrinaría José del Val y Bastida, contador de las Reales Minas. Por cierto, que moriría muy joven, con tan solo 17 años en febrero de 1808. Y su hermano, José en $^{36}$ Sergio Rafael, que nació en octubre de 1793 y fue sacado de la pila bautismal por el mismo contador.

A pesar de tener tan pequeños a sus hijos acepta Francisco de la Garza un viaje de estudios a tierras germanas, junto a Diego Larrañaga, en abril de 1796. Para ese cometido recibirá un sueldo de 12.000 rs., a los que hay que añadir otros 8.000 rs., por una sola vez, en concepto de gastos de viaje. $\mathrm{D}^{\mathrm{a}}$ Antonia, que se quedará en Almadén, recibirá los seis rs. diarios que gozaba su marido como paga. A su regreso y en sucesivas etapas ocupará cargos de distintas responsabilidades entre las que destaca el teniente de superintendente en Almadenejos y, tras las guerras napoleónicas, la dirección de la

32. A.Dio-CR. Libro $5^{\circ}$ de las partidas de desposorios, f. 216. Allí don Gerónimo, tal vez por confusión, aparece anotado con idénticos apellidos que el padre, situación que se repite cuando se anota los padres de la novia. Él era más joven, pues contaba con 31 años y ella 39.

33. AHN. F.C. Minas Almadén. Legajo 1307 (2)

34. Para tan significativo personaje, vid: Matilla TASCón, A. Historia de las Minas de Almadén, ... pp. 149-157; y PElAYo LóPEZ, F.: «La adquisición de las técnicas mineras en la España de la Ilustración (1770-1800)». En FERnÁndez PÉREZ, J. y GonZÁlez TAsCón, I. (Editores). Ciencia, Técnica y Estado en la España Ilustrada. S.E.H.C.Y.T., Madrid, 1990, pp. 73-87.

35. Para su nacimiento A.Dio-CR, Libro de Bautismos, $\mathrm{n}^{\circ}$ 15, f. 321; para su óbito A.Dio-CR, Libro de defunciones, $\mathrm{n}^{\circ} 7$, f. 162 .

36. Si se desea consultar su partida de nacimiento, A.Dio-CR, Libro 16 de Bautismos, f. 43. 
Academia de Minas, en unos momentos especialmente complejos para la institución docente.

Si antes decíamos que eran los únicos nietos es porque de Rafael ya mencionamos que murió mozo soltero y su otra hija, Luciana, no tendrá descendencia. Ésta se desposó primero con el archivero de la Contaduría, el palentino Jacinto Valiente ${ }^{37}$, hombre de frágil salud del que enviudó en 1793. Una década más tarde contrajo segundas nupcias con el comerciante Juan Manjón ${ }^{38}$, persona de cierta fortuna, pues lo hemos encontrado en los protocolos notariales de esos años en diferentes compraventas de propiedades.

Nuestro galeno, desde que llegó a esta población en la correspondencia epistolar y el registro de sus informes se mostrará orgulloso de ejercer como médico de las Reales Minas de Azogue, de su Real Fabrica, tropa de su resguardo, Real Hospital de Mineros y Carcel de Forzados. Por su actividad percibirá una asignación idéntica a la de su antecesor, 500 ducados; eso sí, mejorada tras el fallecimiento de López de Arévalo, en 1765, pues ya no tendría que abonar los cien ducados de pensión. A ello habría que añadir otras mejoras: el carro de leña, que le correspondía según las ordenanzas de minas o los cántaros que en verano se distribuían entre los más relevantes cargos de la mina. En concreto a él se le asignaron cuatro cántaros para el gasto de su casa $^{39}$. En reiteradas ocasiones solicitará un incremento de sueldo, lo que consiguió, primero en 1775 y luego en 1784. También luchará con denuedo por que se le reconociese el título de médico de la Real Familia. Muestra de ello es que en junio de 1786 lo volverá a reclamar y aun emitiéndose el informe favorable del teniente de gobernador de Almadén, Carlos III no le concederá ese honor, aunque para reconfortarle le diga a través del marqués de Sonora, que lo ha de tener presente para premiarle de otro modo ${ }^{40}$. Esta distinción finalmente la alcanzará de Carlos IV, en la primavera de 1798, cuando atendiendo al mérito y servicios prestados $S$. M. se ha dignado concederle los honores de medico de su $R^{l}$. Familia. Un reconocimiento que llegaba evidentemente tarde, pero que serviría para reconfortarle a tan solo unos meses de su fallecimiento en el otoño de $1798^{41}$ y ser enterrado en el camposanto del Real Hospital de San Rafael.

37. De origen palentino, tuvo que solicitar en reiteradas ocasiones licencias por enfermedad. Así se recoge en la documentación del AHN. F.C. Legajo 200 (1), donde al menos desde 1785 gozó de permisos para intentar recobrar la salud.

38. A.Dio-CR, Libro de Desposorios $n^{\circ} 8$, f. 102. Donde se recoge la fecha de la ceremonia, 10 de octubre de 1803 y la edad de los contrayentes; él de 23 años y ella de 36, naturales ambos de Almadén.

39. Anes Álvarez de Castrillón, G. Biblioteca personal custodiada en la Real Academia de la Historia. 40. AHN. F.C. Minas de Almadén. Legajo 200 (1)

41. A.Dio-CR. Libro $6^{\circ}$ de defunciones de Nuestra Señora de la Estrella, f. 305. Allí aparece como viudo y deja por herederas a sus dos hijas: Antonia y Luciana. Para tener mayor detalle se puede consultar el apéndice documental. 


\section{5.- MÁS ALLÁ DE LA MEDICINA. SUS RESPONSABILIDADES MUNICIPALES}

Una década después de llegar a Almadén comienza a desarrollar sus responsabilidades concejiles. Estas se van a prolongar durante tres lustros, en los más variados cargos. El primero de ellos, según Matilla Tascón, fue en 1768 cuando resultó elegido procurador síndico personero en el ayuntamiento almadenense ${ }^{42}$. De los problemas que se encontró en su cargo y de los disgustos que le originó el enfrentamiento con el visitador de azogues y asesor del superintendente-gobernador, el archivero Matilla da gran pormenor. Nada hacía presagiar estos desencuentros, pues ya hemos comentado que tan sólo unos años antes había sido el superintendente el padrino de sus dos hijas.

Lo que sí hemos podido constatar en los archivos locales es su primer compromiso como procurador síndico en 1770 . Cuando se lleve a término la elección anual de cargos municipales a propuesta del gobernador y superintendente: D. Diego Luís Gijón Pacheco y Sanvictores. Allí va a coincidir con sus cuñados, Francisco y Juan Ramiro Arcayos, como regidores. El sistema empleado para la elección era la entrega de diez bolas blancas y otras tantas negras, por parte del escribano municipal, para conocer el respaldo de las propuestas presentadas. En ese momento otros regidores no tuvieron el apoyo unánime que el mataroní obtuvo: (...) Su señoria propuso por Procurador Sindico General a D Joseph Pares y Franques y habiendose votado en la misma forma que los antezedentes quedo electo con todos los votos blancos ${ }^{43}$. Esta votación se efectuó el primer día del año y justo en la jornada siguiente, el dos de enero, se procedió a la aceptación y juramento del cargo. Lo encontramos con sus nuevos compañeros, todos los presentes dijeron que aceptaban y azeptaron en toda forma y juraron, por Dios Nro. Señor y a una señal de cruz, cumplir exactamente con sus respectibos oficios bien y lealmente y lo firmaron con su señoria.

En los meses venideros, ya dentro de sus quehaceres municipales, se va a dar la curiosa circunstancia de que el médico de la municipalidad, D. Blas de Barberá se marcha a Pozoblanco y se presenta para el puesto vacante D. Juan Gómez del Barrio, que ejercía en Agudo. El cabildo tiene que decidir la idoneidad del aspirante y establecer las capitulaciones del nuevo contrato. Allí está de nuevo Parés ${ }^{44}$ y tendrá que respaldar con su voto la decisión de la corporación. En otras ocasiones la rúbrica aparece tras

42. Matilla TASCÓn, A. Op. cit., t. II, pp. 434-436. Este nombramiento de 1768 no se ha reflejado en los libros municipales que se custodian en el AMA, pues en ese año concreto no es él a quien proponen para ese oficio, ni para ningún otro. Posiblemente se apoyó en la documentación del AHN. F.C. Minas de Almadén. Legajo 1307, donde sí que figura nuestro médico.

43. AMA. Legajo 35.

44. AMA. Legajo 34. Como curiosa circunstancia se anota en la segunda obligación que el citado D. Blas tendrá que visitar sin intereses y gratuitamente, como es practica a los señores de este Ayuntamiento, como son su señoría el sr Gobernador, o en su lugar a su theniente; los quatro srs. rexidores, Procurador Sindico y escrivano de dicho ayuntamiento (...) y en la misma manera a sus familias, esto siempre que haya nezesidad; con la precisa obligazion de que a de asistir aunque concurra otro médico, pues no por esto se a de escusar" 
resolver cuestiones más cotidianas, aunque de no menor interés, como el incremento del precio del pan, en el otoño de ese mismo año.

De su dilatada hoja de responsabilidades y servicios municipales hacemos a continuación un breve extracto:

\begin{tabular}{|l|l|}
\hline Año & \multicolumn{1}{|c|}{ Ocupación } \\
\hline 1770 & Procurador Sindico General \\
\hline 1771 & Padre General de Menores \\
\hline 1772 & Procurador Síndico \\
\hline 1773 & Comisario del Sto. Rosario \\
\hline 1774 & Mayordomo de la Iglesia Parroquial. \\
\hline 1775 & Mayordomo de la Iglesia Parroquial y del Santísimo. \\
\hline 1776 & Mayordomo del Santísimo. \\
\hline 1777 & Segundo Regidor municipal \\
\hline 1778 & Mayordomo de la Iglesia Parroquial. \\
\hline 1779 & Mayordomo de la Iglesia Parroquial y del Santísimo. \\
\hline 1780 & Mayordomo de la Iglesia Parroquial y del Santísimo \\
\hline 1781 & Mayordomo de la Iglesia Parroquial y del Santísimo. \\
\hline 1782 & Mayordomo de la Iglesia Parroquial y del Santísimo. \\
\hline 1783 & $\begin{array}{l}\text { Procurador Síndico. Mayordomo de la Iglesia Parroquial y del Santísimo. Padre } \\
\text { General de menores. }\end{array}$ \\
\hline 1784 & Mayordomo de la Iglesia Parroquial y del Santísimo. \\
\hline 1785 & Mayordomo del Santísimo. \\
\hline
\end{tabular}

Elaborado a partir de la documentación del AMA, legajos 34 y 35.

Aunque la mejor síntesis de sus tareas públicas sean sus propias palabras tras ser honrado para diferentes ocupaciones en unos momentos en que su salud, a los sesenta y tres años de edad, no parece respetarle: la ofendida respiración me inhabilita a todo exercicio violento, tanto que para cumplir menos mal con los principales objetos de mi facultad he despedido generalmente los enfermos que no son de mi obligación; mi cansancio es tal que de dos años y medio a esta parte no me permite ni andar a cavallo, tomando a mejor partido sufrir a pie los calores del verano, y las aguas, barros y nieves del invierno.

Recuerda las distintas responsabilidades que ha asumido en los años anteriores:

(...) he servido tres años los empleos de alcalde de barrio, tres el de Procurador Sindico General, dos o tres el de Personero, uno el de Regidor, diferentes comisiones de acopios de granos y quanto han gustado mandarme los señores jueces y capitulares de esta villa ${ }^{45}$.

Por ello, agradecido por el ofrecimiento que se le hace, pide a quien lo propone le dispense del encargo de Procurador Síndico, por los obstáculos de salud antes citados.

45. AMA. Legajo 35.- Ver el documento completo en el apéndice documental. 
Aún así muestra su sentido del deber al incluir en la súplica que si fuese menester se sacrificaría, si el superintendente considerase un menosprecio el rechazo de ese cargo.

A la vista de los lazos familiares ${ }^{46} \mathrm{y}$ ocupaciones municipales aquí expuestas podemos afirmar que formó parte de la elite municipal, pues los vínculos que va tejiendo a lo largo de su permanencia le hacen ir formando parte de un grupo social que reiteradamente ocupa puestos destacados en la estructura social de la villa minera.

\section{6.- ¿CÓMO ERA EL ALMADÉN DE LA SEGUNDA MITAD DEL S. XVIII?}

La segunda mitad del setecientos, época en que nuestro galeno es testigo directo de los acontecimientos, está salpicada de luces y sombras. Desde luego es un periodo brillante con la presencia de grandes hombres de ciencia: el superintendente Francisco Javier de Villegas, Francisco Nagle, Guillermo Bowles, Antonio de Ulloa, Jorge Juan, los ingenieros sajones que dirigirán la Academia de minas (C. Köehler, E.C. Storr, J.M. Hoppensack), Agustín de Betancourt, Tomás de Estala, etc. Pero al mismo tiempo marcada por las secuelas del incendio de 1755 , por la estricta moral emanada de los dictámenes de Trento y por los avatares, como toda sociedad preindustrial, de las alteraciones climáticas que arrastrarán a la población a serias penurias cíclicas (como los difíciles los años de la década de los sesenta). Hagamos un breve recorrido por el paisaje y el paisanaje de aquellas décadas.

El Almadén dieciochesco ocupaba una extensión significativamente inferior al actual. La planimetría estaba vertebrada por el eje principal de su calle mayor de San Juan, cayendo a su vertiente meridional y septentrional un irregular entramado callejero condicionado por la inclinación del terreno. Los ingenieros Bernáldez y Rúa Figueroa $^{47}$, al referirse a la situación sanitaria que se vivió en los años de 1751 y 1752 nos hablan de la necesidad de ampliar el número de viviendas para dar cabida a los forasteros que acudían a trabajar temporalmente a las minas ya que tenían que dormir al descubierto o en chozas que ellos fabricaban de poco resguardo, por hallarse ocupadas las 480 casas que entonces componían el todo de su población.

\footnotetext{
46. Su vinculación familiar es intensa con la administración minera. Su mujer es hermana del Mayordomo de Buitrones, Juan Ramiro Arcayos; su cuñado Jerónimo Cuenca era empleado en el exerzicio de maestro sobreestante de las reales obras. Su hija Luciana, se casaría con Jacinto Valiente, archivero de la Contaduría, y su otra hija Antonia, con don Francisco de la Garza, futuro director de la Academia minera. De sus hijos varones, se sabe que uno falleció cuando ocupaba una oficialía de la Contaduría, mientras que Rafael viajó a Indias. De él se puede ampliar noticia consultando en el AGI. Contratación, 5529, N.2, R.121, la licencia para pasar al reino del Perú, en otoño de 1785, de Rafael Parés y Ramiro, natural de la villa de Almaden y residente en esta ciudad (Cádiz). ya que contaba con la documentación requerida y el permiso del excmo. Sr. D. Joseph de Galbez del Consejo de S. M. y Secretario del Despacho Universal de Indias y en atención a ser natural originario de estos reynos como lo acredita la fee de baptismo que con ygual solemnidad presento, y también la licencia para dicho viaje me concede el Dr. D. Joseph Parés, mi padre.
}

47. Bernáldez, F. y Rúa FigueroA, R. Revista Minera, t. XIII, p. 5. 
El catastro de Ensenada ${ }^{48}$, realizado en aquellos mismos años, es la más valiosa fuente de información. Nos detalla con pormenor, calle a calle, los distintos vecinos e inquilinos que viven en la localidad. Especifica además las casas pertenecientes a la monarquía repartidas por todo el entramado urbano: la que llaman de la Superintendencia, destinada por ordenanza para habitar los señores superintendentes y para las oficinas de la Contaduría y Pagaduría, que se ubica frente de la iglesia; las casas del Contador, contiguas a la misma Iglesia; la del oficial de la tropa que custodia las reales fábricas y minas en la calle Mayor; o la casa que como gran Maestre tiene para ser ocupada por los alcaldes mayores. En cualquier caso, los cambios que va a sufrir en breve la silueta urbana serán espectaculares: en las eras se construirá la plaza de toros, en sus cercanías el hospital y algo más allá la cárcel nueva. Todas estas edificaciones se levantarán en lugares alejados del casco urbano, pero que en breve modificarán la disposición del callejero.

En este contexto y solo dos años antes de la llegada de Parés hay que recordar que se había extinguido el incendio originado en enero de 1755. Va a ser una ocasión triste, pero inmejorable para conocer la religiosidad del paisanaje. En tan delicado trance, como no se podían atajar las llamas por medios naturales, se mandaron celebrar rogativas a Nuestro Padre Jesús Nazareno ${ }^{49}$ venerado en su ermita de Almadén y a San Antonio de Padua, del convento de San Francisco, extramuros de Chillón. Al constatar que no había forma de sofocarlo, unos meses después se volvió a mirar al cielo y pedir el socorro divino, esta vez a Nuestra Señora de Gargantiel $^{50}$, de enorme predicamento en la villa. Así lo recoge el libro de acuerdos del ayuntamiento, cuando en marzo de ese mismo año, bajo la presidencia de Francisco Javier de Villegas, se acordó: que por causa del ynzendio que se advirtio en ella es mucha la necesidad que padeze el vecindario de la mayor considerazion el perjuizio de la corona, por ser esta mina la mas rica y avundante de metales y deseando la villa contribuir al bien del Reyno y al de su comun y en corresponder a los beneficios que recibe de $S$. M. ha acordado y dispuesto

48. Los datos del Catastro de Ensenada referentes a Almadén se pueden consultar en el Archivo Histórico Provincial de Ciudad Real, (AHP-CR), legajos 642 y 643. En la actualidad se puede indagar sobre el interrogatorio a través del programa PARES del Ministerio de Cultura.

49. Sobre la efigie del Nazareno, cabe comentar que fue una de las escasas imágenes que se salvaron de la quema en los tristes sucesos del verano de 1936. Sin embargo, un desgraciado accidente, en 1954, la reduciría a cenizas. Recientemente el historiador José Rafael GONZÁLEZ ROMERo ha sacado a la luz la autoría gracias a un documento, prácticamente desconocido y mal interpretado, que se escondía en el interior del torso. El escrito custodiado, en la actualidad, por el Hermano Mayor de la cofradía nos permite afirmar que la talla Jesús con la Cruz a cuestas era obra de María Roldan (hija del también escultor sevillano Pedro Roldán) y de su marido Matías de Brunenque, fechada en Sevilla, el veintidós de junio de mil seiscientos noventa y nueve. Lo que vendría a ratificar los enormes vínculos que se establecen entre la ciudad hispalense y esta villa manchega.

50. La imagen que hoy se conserva está decapitada y sólo se aprecia la media luna, junto al cordón y medalla con la cruz de Calatrava. 
a representacion verbal del señor Supte. se aga rogatiba a Nra. Señora de Gargantiel, protectora en todas las afliciones de este pueblo. ${ }^{51}$

Ya andando 1756 se comprobó que se corrían las llamaradas hacia la otra parte de la mina. Se pidió esta vez al Arzobispo de Toledo autorización para trasladar la imagen de Nuestra Señora del Fuego, del pueblo de Garlitos ${ }^{52}$. Tras disquisiciones sobre cómo controlar el fuego y volver a poner en explotación los pozos mineros se tornó a las rogativas a todas las imágenes cercanas, incluida la de Nuestra Señora de la Estrella, patrona de la villa. Por más procesiones, rogativas y peticiones celestiales el fuego terminó por consumirse en el verano de 1757, tras treinta meses. No se llegó a una conclusión firme sobre la causa que originó tan enorme pérdida, pero todas las miradas apuntaban a los forzados. Por ese clima de desconfianza, rara vez se les volvió a permitir trabajar en el interior de los pozos, lo que redundó en su salud. El médico catalán, en su Apología, nos lo aclara: (...) oy no enferman de males minerales, pues no se destinan como antes a los más profundos y peligrosos trabajaderos. Es el caso que en el incendio de 1755 se creyó que la mala indole de esta gente huviese pegado fuego a los maderos mas secos; y por esta razon se retiraron los forzados de lo interior de ellas, y se destinaron a los superficiales ${ }^{53}$.

Sólo dos años después de haber recalado el galeno mataroní, en la primavera de $1761^{54}$, se va a efectuar la visita eclesiástica a esta población. Esta circunstancia nos permite profundizar en la idiosincrasia religiosa del momento. Como en el resto de España, cualquier actividad va a estar impregnada por el ambiente contrarreformista posterior al Concilio de Trento y fiel reflejo de ello va a ser el testimonio recogido en los libros parroquiales, donde se manda y ordena que todos los eclesiásticos traigan corona abierta, onesto traje y havito que se les manda usar conforme a la dignidad, clase y orden en que estan constituidos bajo la pena prebenida, y declarada en dicha constituzion y Santo Conzilio de Trento. Apostillando que para mayor decencia y decoro se asistan con sobrepellices ${ }^{55}$ a las prozesiones generales que en el pueblo se hagan de Corpus, letanias y otras que sean por la paz, salud, temporales o voto de villa,

51. En el Archivo Municipal de Almadén, legajo 33, quedan recogidas tanto iniciativas sobre el fuego, como singularmente noticias relacionadas con los actos religiosos que dependían del cabildo municipal.

52. Hoy en día no pertenece a Garlitos, sino a Baterno (Badajoz). Se ubica a las afueras de la localidad, en la ermita de Nuestra Señora de la Soledad del Fuego. La fundación se conecta con un suceso acaecido en 1672 en Madrid y en el que, con ocasión de un incendio ocurrido en la Panadería de la Plaza Mayor, un hombre salvó la vida encomendándose a su protección. En recuerdo de este episodio se levantó en el siglo XVIII esta ermita a la Virgen.

53. PARÉS Y FRANQUÉS, J. Apología, op. cit, capítulo 117.

54. A.Dio-CR. Libro $4^{\circ}$ de defunciones, folio 130 y ss.

55. El sobrepelliz es una vestidura eclesiástica de lino parecida al alba pero más corta y que se lleva sin ceñir al cuerpo. Su nombre tiene origen en los países del Norte de Europa en los que se llevó sobre los vestidos fabricados en piel. Su largura que al principio llegaba hasta los pies del oficiante, se fue acortando desde el siglo XIV y a lo largo del siglo XVII se redujo hasta poco más abajo de la cintura, acortándose las mangas y llenándose de rizos. Cuando éstas se suprimen, el sobrepelliz se convierte en colobium o garnacha (derivando en roquete de sacristanes). 
sin que lleben por la tan asistencia, derechos ni limosna alguna, sancionándose su incumplimiento con cuatro reales, aplicados conforme el signodo de este arzobispado. En esa misma visita, se escandaliza porque muchas noches salen por el pueblo a funziones mugeres tapadas, introduziendose y permaneziendo en la misma forma donde las hay bailando con el mismo traje, lo que en opinión del visitador había acarreado muchos y graves inconvenientes, a pesar de que lo había intentado atajar el entonces superintendente D. Diego Luis Gijón Pacheco y San Víctores con duras advertencias de excomunión y multas económicas.

Por último, hay que tener muy presente la trayectoria histórica de Almadén, que tradicionalmente había sido punto de confluencia de religiones diversas. Desde la llegada en 1570 de noventa y tres familias moriscas, resultado de las revueltas alpujarreñas $^{56}$, hasta la presencia de familias protestantes que acompañaban a los mineros y técnicos sajones a partir del mencionado incendio de 1755. Además, hasta aquellos pozos van a recalar, como forzados y esclavos, algunos contingentes significativos de población mayoritariamente mora y berberisca, que si bien en algún caso hace apostasía de su fe, en otros se mantendrá fiel a sus creencias (de ello se tiene constancia en el diferente tratamiento a la hora de fallecer, pues a los primeros se les podrá sepultar en la iglesia parroquial y al resto se les arrojará a alguna mineta abandonada).

\section{7.- CONDICIONES SANITARIAS. MINERÍA E HIDRARGIRISMO}

Las condiciones externas de los mineros no fueron siempre las idóneas, pues hubo años de inundaciones $(1759,1760$ y 1766$)$ y otros de extrema sequía, heladas que no permitieron los levantes o calores rigurosísimos que impedían la actividad física. Sin embargo lo que mayor repercusión tuvo en su salud fue el trabajo en las entrañas subterráneas. La preocupación por las cuestiones higiénico-sanitarias no era una novedad, pues ya en el siglo anterior se habían oído voces que reclamaban una mejor asistencia a aquellos. Pero va a ser ahora cuando se piense en la atención de los pacientes y se solicite la construcción de un nuevo hospital, muy en la línea paternalista que tenía del Estado. Su fundación a partir de 1752 no implica su inmediata puesta en funcionamiento, pues esto último no se produciría hasta 1774. La asistencia sanitaria no era novedad en los cercos mineros: los distintos asientos del XVI y XVII establecían capítulos en los que se obligaba la contratación de personal sanitario. También las Ordenanzas de 1735 recogían el organigrama que debía corresponder a ese hospital. Allí se contemplaba la obligación que tenía el médico de asistir, amén de los reos, a las familias de la Superintendencia, Contaduría y Pagaduría.

Muy en la argumentación mercantilista de reposición de la fuerza de trabajo, el superintendente Villegas exponía al ministro Carvajal la necesidad de contar con un nuevo nosocomio, pues el de la ciudad, conocido como Hospital de la Caridad, era muy limitado de aforo y de personal sanitario, especialmente tras las secuelas que dejó la

56. AHN. F.C. Minas de Almadén. Legajo 1556, caja 1. Más tarde se intentará ampliar el número de familias moriscas hasta las doscientas, que como es obvio, sufrieron un drástico final con la expulsión de 1609. 
epidemia de 1751: en el año pasado se enterraron mas de trescientos treinta cuerpos, entre ellos treinta forzados y regulo según el vecindario que se corresponden a más de un diez por ciento $^{57}$. Hay que pensar que para evitar la propagación de las fiebres los presidiarios se tuvieron que sacar de la Crujía, enfermería de la Cárcel, e instalarlos en la ermita de Jesús Nazareno y en la iglesia parroquial, al cuidado de la tropa y de la población civil, mientras duró ese episodio. Abundando en esta petición, de nuevo Villegas argumenta que hay más de sesenta forzados en camas y que sería una indecencia que se oficie misa en tan malas condiciones espirituales y sanitarias.

El problema a resolver era como estructurar el sostén económico que permitiese tanto la edificación, como el mantenimiento del hospital. Para ello se enlazó la construcción de veinticuatro nuevas viviendas y el coso taurino, que las delimitaba hexagonalmente, con la edificación del hospital, pues con los ingresos recaudados en los arriendos de las instalaciones y la utilización de las mismas se podría costear las obras del sanatorio. Es más, la línea de financiación del superintendente es bien explícita, además del caudal de multas que llevo aplicadas al Hospital, convendrá permitir cada año seis u ocho fiestas de toros y su producto destinado a la construcción de un hospital distinto al ordinario, sentenciando: pues sin él sucederá a los forasteros que acudan a estos trabajos lo que a los indios mitayos ${ }^{58}$.

No hay que olvidar la larga vinculación que tenía la institución hospitalaria con la tradición taurina de esta villa. Muy posiblemente ésta última vinculada a la permanente presencia de grandes manadas de vacadas y reses en toda la jurisdicción almadenense. Incluso antes de construir el coso taurino, en 1744, para celebrar la festividad estival de San Pantaleón, además de los oficios religiosos que requiere la ocasión, los regidores municipales acuerdan se disponga y haga un festín de toros, nombrándose los comisarios correspondientes para que todo esté correctamente supervisado y se despache mandamiento para que el alcalde del lugar del Alamillo, con sus moradores haga traer a esta plaza y sus toriles un encierro de capeos de los mejores que ayga en la vacada de dicho lugar. Se les indica que procuren advertir de tal circunstancia a los comisarios y al mayordomo de propios de la villa, quien debe comprar y preparar a los señores capitulares del municipio la merienda para esa tarde ${ }^{59}$.

Si eso ocurría antes de poner en pie el recinto, en cuanto éste se pueda destinar a ese fin, como en el año 1757, se ordenará que se celebre la festividad de Santa Ana y

57. AHN. F.C. Minas de Almadén. Legajo 772 (2)

58. AHN. F.C. Minas de Almadén. Legajo 772 (2). El texto está datado en Almadén a 2 de agosto de 1752 y hace referencia al sistema de mitas (sistema laboral originario de la región andina consistente en la selección de campesinos de un ayllu determinado para emplearlas en un trabajo a favor de un Estado o gobernante) que imperó en los virreinatos americanos. Muchos de aquellos desafortunados indígenas fallecieron exhaustos en las labores mineras.

59. AMA. Legajo 32, recoge tanto la festividad que aquí se hace mención, como la del año siguiente, 1745, cuando estando en obras la ermita de Jesús Nazareno se trasladan los festejos a la plaza del Sr. S. Juan; por lo que se han de engalanar todas las ventanas, balcones y tablados de la plaza del N. Sr. S. Juan, donde se han de lidiar los toros y capeos, ajustándose los precios de los asientos y ventanas. 
San Pantaleón, además de las misas y procesiones acostumbradas: se tenga una corrida de capeos en la Plaza Nueva destinada para corridas de toros y capeos $^{60}$. Claro está que cuando se organizan estos saraos taurinos no se piensa que pueden ocurrir desgracias, como la acontecida en fecha tan destacada como la de San Miguel, el 29 de septiembre de 1783, cuando el torero sevillano José María falleció ${ }^{61}$.

Además, conviene anotar que si durante la primera mitad del setecientos la irregularidad en la fase productiva del azogue fue la tónica predominante, en la segunda parte de la centuria se apostó por una fase expansionista con la finalidad de incrementar los ingresos hacendísticos. Aunque no se vendía el ingrediente mercurial a precios reales de mercado, sí que las entradas en las arcas estatales fue considerable por los beneficios que reportó en las cecas indianas y nacionales. Con este incremento productivo fue parejo una mayor exigencia a los mineros que veían incrementar sus bajadas a los pozos y por tanto su tiempo de exposición a un medio tan hostil como las cárcavas mercuriales.

Las repercusiones en su salud fueron evidentes, la salivación excesiva y los temblores se incrementaban mostrando los más claros síntomas del azogamiento. Las bajas y las incapacitaciones laborales por este motivo fueron en aumento, lo que en más de una ocasión condicionó la disponibilidad de mano de obra para las distintas operaciones de extracción y destilación del cinabrio. Por mucho que las faenas más duras finalizaran con los rigores estivales, el saneamiento de los operarios se veía perjudicado si a las pocas semanas se volvía a la faena.

Los dirigentes del establecimiento pusieron énfasis en la recuperación de los trabajadores imposibilitados. En primer lugar, se garantizaba la prestación de cuidados médico-quirúrgicos a los trabajadores enfermos o accidentados, amén de dispensar en condiciones ventajosas las medicinas necesarias para su recuperación. Para ello las minas contaron con la presencia de médicos, cirujanos, boticarios y enfermeros destinados a los trabajadores de la explotación y sus familias, es decir, aquéllos que contribuyeran de forma real o potencial al trabajo productivo. Además, otro aspecto interesante de constatar fue la concesión de limosnas a los mineros inhabilitados o, en caso de fallecimiento, a sus viudas y huérfanos. Esta práctica asistencial se regularizó desde que la hacienda retomó el control de las minas (mediados del siglo XVII) y su concesión estuvo generalmente limitada a los trabajadores naturales de la villa como complemento a la prestación de cuidados domiciliarios por parte del médico y cirujano de los cercos mercuriales. La acreditación del origen profesional de los males que

60. AMA. Legajo 33. Se ha optado por poner esa fecha, pero en el Archivo municipal se pueden recoger múltiple ejemplos de esos festejos anuales.

61. A.Dio-CR. Libro de Defunciones de Almadén no 5, f. 354. Textualmente dice así:

En la $Y^{a}$ Parroquial de Nra. Sa de la Estrella de esta villa de Almadén, en veinte y nueve de septiembre de mil settecienttos ochenta y tres años se enterro en el tramo cattorze (habiendo recibido los Stos. Sacramentos) a Josef Maria mozo soltero (según decía) natural de la ziudad de Sevilla; criado en el barrio que llaman en dicha ziudad de San Bernardo, su edad era como de veinte y quatro a veinte y cinco años, su exercicio hera el de torero; $y$ lo firme = Heredia. 
provocaban la incapacitación se convirtió en requisito imprescindible para acceder a las ayudas (licencias de panadeo y/o acceso a regentar puestos públicos vinculados al municipio), y se otorgó a los facultativos de las minas la competencia y responsabilidad en la gestión de esta modalidad asistencial.

Para finalizar este apartado, otros asuntos perniciosos afectaban a la salud y a la moral de los mineros a las que Parés consagró el segundo tratado, la Catástrofe $e^{62}$. Nos referimos a la libidinosidad del mineraje, relacionado con su actividad sexual o con la gula, convertidas por nuestro ilustrado galeno en enfermedades que reconocían su origen, al igual que el temblor, la salivación o la tisis, en la inhalación de partículas de mercurio. Lejos de apelar a la templanza de carácter o la moderación de la ingesta, propuestas tradicionales de la dietética clásica, Parés aplicó a sus propuestas terapéuticas un inequívoco marchamo moralizador: continencia, humildad, sumisión, paciencia... en fin, sometimiento a la voluntad divina y al servicio del Rey.

\section{8.- SU LEGADO INTELECTUAL}

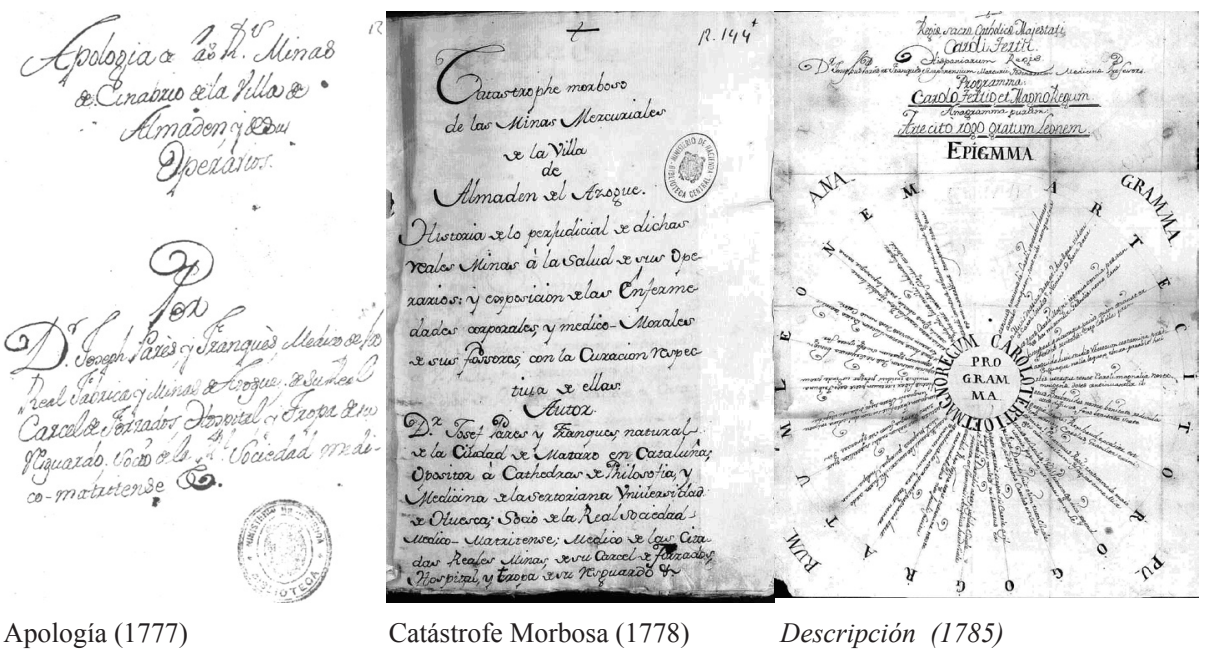

Como ilustrado galeno, su interés por las cuestiones que le circundan le hizo dejar por escrito numerosas reflexiones. Unas, como era lógico, vinculadas a su profesión. Como ya se ha comentado en el Archivo Parroquial de Almodóvar del Campo ${ }^{63}$, existe un protocolo notarial donde Parés otorga poderes para que se publique su obra Apologema de la mas verosimil medicina, para que se pueda conseguir con ella

62. En este terreno nos son muy válidas las aportaciones de MENÉNDEZ NAVARRO, A. y RodRÍGUEZ OCAÑA, E.: «Salud, trabajo y medicina en la España Ilustrada». Archivos de prevención de riesgos laborales; vol. $8, \mathrm{n}^{\mathrm{o}} 1,2005$, pp. 4-13.

63. Libro $4^{\circ}$ de Crónicas de la Parroquia de la Asunción de Almodóvar del Campo, f. 83 r-v. 
mayores luces para el mejor gobierno y prudencia del modo curatibo con arreglo a sus doctrinas que a su parecer ban fundadas las reglas medicas. Por cierto, unos años después, cuando en 1775 termine de redactar su Apología, se mostrará más cauteloso y comedido, al afirmar que tiene varias piezas manuscritas tocantes a mi facultad medica y tiemblo de darlas al publico por dudar si sere suficiente a instruirle y aprovecharle ${ }^{64}$.

Unas líneas más adelante comenta que también tenía muy avanzadas La Historia de las Reales Minas y la Catástrofe Morbosa. De la primera no hemos vuelto a tener conocimiento, aunque bien pudiera estar englobada en la Descripción (en cualquier caso sus conocimientos históricos quedan bien contrastados en los tres manuscritos que a continuación detallaremos), de la segunda sí que daremos cumplida cuenta.

Vayamos con la trilogía de manuscritos, pues es en ellos donde se recoge todo su saber y curiosidad intelectual, lástima que los responsables de su impresión no tuvieran el mismo criterio cuando correspondió. Hoy los tres originales se custodian en el Archivo del Ministerio de Economía y Hacienda.

Comenzaremos, siguiendo el orden cronológico de su redacción, por la Apología de las Reales Minas de Cinabrio de la Villa de Almadén del Azogue y de sus operarios, obra dirigida a la Sacra, Católica y Real Majestad D. Carlos Tercero, en 1777. Prácticamente toda ella se convierte en una excusa para ir desmontando todas las teorías que dos años antes aportó Guillermo Bowles, en su Introducción a la Historia Natural y a la Geografía Física de España ${ }^{65}$. Pero su lectura, amén de los varapalos constantes al naturalista irlandés, tiene un sustrato histórico y científico de cierto valor, ya que para refutar con mayor rotundidad las afirmaciones de Bowles trata de acudir a los grandes referentes históricos (Plinio, Teofrasto, Estrabón), a eminentes físicos ${ }^{66}$ (Henckel, Agrícola, Hoffmann, Lemery, o Becher) o ilustrados modernos nacionales (Solórzano, Gamboa, Barba, el padre Zaragoza, Jorge Juan, Ulloa, etc.).

Al mismo tiempo es una buena oportunidad para ir conociendo algunos hechos relevantes de las minas: desde la explotación por los romanos, a los asientos con los Fúcares, el cambio administrativo de 1646 cuando estos cesaron, los distintos incendios de 1639, 1693 y 1755, o la valía de sus operarios a los que ninguneaba el irlandés cuando en abril de 1738 visitaron los descubrimientos de la Alcoraya en Alicante ${ }^{67} \mathrm{o}$

64. PARÉS y FRANQUÉs, J. Apología, op. cit., capítulo 167.

65. Bowles, G. Introducción a la Historia Natural y a la Geografía Física de España. Madrid, Imprenta de D. Francisco Manuel de Mena, año de 1775. Reproducción facsímil en Madrid, 1982.

66. Sirvan como ejemplo citados: Johann Friedrich Von Henckel (1678 - 1744), médico muy versado en mineralogía y química, que como él ejerció la medicina en las minas sajonas de Freiberg; Nicolás Lemery (1645-1715) químico francés, que había publicado en 1675 el Cours de Chymie; o el alquimista alemán Johann Joachim Becher (1635 - 1682) y su Physica Subterranea.

67. PARÉS Y FRANQUÉS, J. Apología, op. cit., capítulo 24. Textualmente se recoge así: en consequencia a la pericia de los mineros naturales de Almaden salieron de esta villa con orden de S.R. Mag. para Alicante al reconocimiento de ciertas minas de azogue D. Juan Ramiro Arcayos, contador de las de Almadén, Francisco Mayoral, capataz de mina, Alfonso Varea Arcayos, entibador y los destajeros Francisco Casasola y Geronimo Garcia Pizarroso. 
en 1763 inspeccionen los hallazgos de Navalucillos (Toledo). Pero también aporta unas breves pero muy significativas pinceladas sobre la situación que estaban viviendo los forzados, las enfermedades y duras condiciones que tenían que soportar los mineros, los sistemas de cochuras en el cerco de Buitrones, la nocividad de los vapores mercuriales y sus repercusiones en la vegetación, las aguas y el entorno de Almadén.

Por tanto, además de contrarrestar los postulados bowlesianos, en ocasiones con enorme dureza, a lo largo de 168 capítulos y de 234 páginas nos permite adentrarnos en los más diversos temas que rodean a aquellas cárcavas mercuriales: las fatigas de sus mineros, la organización de sus pozos y socavones, las peculiaridades de los hornos de fundición, aspectos sobre la composición mineralógica de sus yacimientos, la producción de azogue cosechada bajo el mandato de distintos superintendentes, incluso algunas poblaciones vecinas donde él ha vivido o que ha visitado.

La segunda obra manuscrita, datada en 1778, es la Catástrofe morboso de las minas mercuriales de la Villa de Almadén del Azogue. Historia de lo perjudicial de dichas Reales Minas a la salud de sus operarios, y exposición de las enfermedades corporales y médico-morales de sus fosores, con la curación respectiva de ellas. De ella tenemos una breve cita del propio superintendente, quien en verano de ese mismo año comunica a D. José Gálvez, que continuaré el reconocimiento de la obra escrita (...) titulada «Colección de observaciones de estas minas, su antigüedad y portentos», la que pasaré a manos de V.E. con mi ynforme, también le proporcionaré escribiente para que concluía el segundo tomo ${ }^{68}$. Esta obra supone una ingente labor nosográfica, al describir en 17 capítulos otras tantas enfermedades consideradas específicas del trabajo en las minas de mercurio. Su familiaridad con el proceso productivo y con la compleja estructura sociolaboral de las minas hacen de esta pieza un testimonio de singular valor y originalidad.

El siniestro panorama sobre la condiciones de vida y trabajo de los mineros que Parés proporcionaba en su texto lo convirtieron en un documento comprometido más allá de su condición de estudio médico. La intencionalidad que guió al médico catalán seguramente era despertar la atención de los responsables políticos, especialmente de Carlos III, al mostrar una completa relación de los males en que se desenvolvía la vida de los mineros. Ya hemos visto en la anterior obra que también allí los exponía, pero ahora lo hace con una mayor minuciosidad. De sus explicaciones no se deduce ni una crítica ni una denuncia al triste panorama laboral que tenían estos operarios. Es más, lo considera como algo natural y consustancial a esta actividad extractiva, como el enorme tributo que estos almadenenses y forasteros prestaban a su soberano y a la nación.

Coincido con el profesor Menéndez Navarro ${ }^{69}$, quien ha realizado importantes aportaciones en este terreno, en que los problemas de salud fueron interpretados por Parés en consonancia con el ideario mercantilista. La pérdida de la salud fue percibida

68. AHN. F.C. Minas de Almadén. Legajo 200 (1). Aclara que no pudo encontrar escribano desocupado que tenga buena letra y escriva según reglas de orthografia que pide.

69. Sobre este autor ver: MENÉNDEZ NAVARRO, A. Catástrofe morboso de las minas mercuriales de la villa de Almadén del Azogue (1778) de José Parés y Franqués. Edición anotada. Cuenca, Universidad de 
como una merma de la capacidad productiva y las funciones prioritarias de la ciencia médica y de los dispositivos asistenciales se orientaron hacia la conservación de niveles de salud compatibles con una larga dedicación a las minas o a recobrar dicha capacidad una vez perdida.

Tal vez el deseo de nuestro ilustrado fue explicar la situación que allí se vivía a diario para argüir y justificar los recursos económicos necesarios para mantener el hospital y sus empleados. Aquellos desgraciados mineros y sus familias no tenían otra posibilidad para subsistir que regresar a sus trabajos, aun a riesgo de quebrantar más su salud, de ahí la importancia de disponer de aquellas instalaciones para su recuperación.

El tercer manuscrito, al que antes aludíamos cuando nuestro autor hablaba que tenía a medio confeccionar una Historia de estas Reales Minas, bien podría tratarse de la Descripción histórico-phisico-médico-mineralógico-mercurial de las reales minas de Azogue de la villa de Almadén. En sus páginas iniciales, además de recoger la fecha (1785), hace ver que su propósito no es otro que el de formar un mineraje mercurial instruido en los mas esenciales principios de estos subterráneos cinabrinos, a fin de que con el conocimiento meramente práctico que tienen de estas maniobras puedan a muy poco trabajo gloriarse de haverse en Almaden exigido una minería tan respetable como qualquiera de la Europa.

Efectivamente, a lo largo de 443 páginas y 327 capítulos/párrafos nos va instruyendo sobre la antigüedad de estos pozos, sobre los episodios más relevantes de su recorrido histórico (sobre si el minio que menciona Plinio para llevarlo a Roma era originario de estas vetas mercuriales, sobre la ubicación de Sisapo, el título de villazgo, la duración de los asientos con los conde Fúcares, las aportaciones de las distintas minas y los nuevos descubrimientos de la mina de Las Cuevas y un largo etcétera). Pero como sucede con las anteriores obras también es una gran oportunidad para conocer temas colaterales: las distintas aldeas y localidades próximas; la información sobre la clasificación de los minerales en solera, requiebro, china, candadillo; las duras condiciones de vida del mineraje; o los distintos sistemas extractivos. Los temas son ya recurrentes, pues se han explicitado con anterioridad, pero Parés no pierde ocasión para demostrar los conocimientos y vivencias adquiridos tras casi tres décadas en aquel lugar.

No quiere dejar pasar la ocasión para volver a incidir en temas moralizantes. Así cuando nos habla de los templos y edificios religiosos aconseja que no estén demasiado recargados de ornamentación, pues distraen y llaman a la vanidad. Incluso la música que se escucha en aquellos recintos sagrados debería estar enfocada únicamente a la mayor grandeza del Señor. En esa misma línea se atreve a apuntar que los religiosos deberían tener cuidado en su forma de vestir y comportarse, pues no siempre van ataviados con la debida compostura que edifique a los fieles.

Desde el punto de vista historiográfico, esta última entrega está mucho más cuidada, ya que al final hay un índice con los principales temas que se han tratado y el

Castilla-La Mancha, 1998 y Un mundo sin sol. La salud de los trabajadores de las minas de Almadén, 1750-1900. Granada, Universidad de Granada, Universidad de Castilla-La Mancha, 1996. 
párrafo donde se pueden localizar y, sobre todo, un diccionario con las voces y términos mineros que hacen más didácticas las explicaciones y aclaran las dudas que se le presenten al lector.

Hasta aquí el extracto de lo más relevante de su obra escrita. Si esta última está datada en 1785, aún le quedarán en su madurez grandes emociones, según hemos esbozado con anterioridad: el viaje de su hijo a tierras americanas ese mismo año, el matrimonio de sus hijas Antonia y Luciana, el nacimiento de sus nietos Natalia y Rafael; pero al mismo tiempo de disgustos y sinsabores, como el que no se reconociese sus aportaciones médicas con la publicación de aquellos manuscritos, el fallecimiento de su hijo o el de su yerno. Luces y sombras para una vida intensa, llena de satisfacciones personales y de frustraciones de un ilustrado que dedicó con coraje sus mejores esfuerzos a sus labores sanitarias y que aportó, bajo el prisma de su mentalidad dieciochesca, para generaciones futuras sus experiencias y reflexiones sobre aquellos cercos mercuriales.

\section{9.- APÉNDICE DOCUMENTAL}

\section{Documento 1.- Desposorio de Joseph Parés Adroguer con Maria Franqués y Picas} (septiembre 1719)

Als tres de satembre del añy mil set cens y dinou foren desposats per paraules de present en presencia del R. Jaume Manent y Castellar, presente (ab llicensia del sr. D. Ramon Riera rector de la iglesia Parroquial de la ciutat de Mataró, bisbat de Barna) Joseph Parés Adroguer, fill legitim y natural del Mag. Dr. en medicina Salvador Parés difunt y de Maria, muller sua vuy vivint d'una part amb Maria Franqués y Picas, doncella filla legitima y natural de Pera Franques Adroguer y de Maria Picas y Franqués, conjuges vivints de part altre tots de la present ciutat de Mataró; ab las solitas acostumadas llicencias y en tot se ha guardar las formas del S.C.J. y us de la iglesia; foren presents per testimonis Joan Vila, esculptor y Jaume Esmendia negociant, tots de la present ciutat de Mataró.

\section{Documento 2.- Partida de nacimiento de Joseph Parés y Franqués (agosto 1720)}

Als vint y nou d'agost del any, il set cens y vint fonch batejat en la fons baptismal de la iglesia parroquial de Sta. Maria de la ciutat de Mataró, bisbat de Barna, per mi Jaume Manerit y Castelar present y resident de dita iglesia ab llisensia del sr. Rector. Salvador Joseph Joan Magi Antoni Pere; fill llegitim y natural de Joseph Parés Adrogue, y de Maria Parés y Franqués, muller sua; foren padrins, D Joseph Picayres y Fornells, corredor d'orella y la sra. Maria Franqués y Picas, viuda, tots de la present ciutat de Mataró. 
Documento 3.- Poder notarial para imprimir el libro Apologema de las mas verosímil Medicina. (junio 1756)

«Protocolo de escripturas publicas otorgadas ante Juan Perez Escobar escribano de Su Majestad publico y del numero de esta villa de Almodóvar del Campo en este presenta año de 1756»

En la villa de Almodóvar del Campo en diez de junio de mill setecientos cinquenta y seis años ante mi el escribano publico y testigos parecio el doctor don Joseph Pares socio de la Real Sociedad Medica Matritense, medico titular desta dicha villa y vecino della, a quien doy fee conozco y dijo que a costa de su mucho trabajo celo y aplicación y en cumplimiento de su facultad y que sus deseos siempre han conspirado y conspiran en el mayor auje y lucimiento que se merece, a travajado y formalizado una obra de utilidad y aumento para dicha facultad intitulada Apologema de la mas verosimil medicina, la qual solicita con ferbor y sumo anelo se dé luz por lo que pueda aprovechar y servir a los profesores de dicha facultad o otras personas curiosas y bien aplicados y conseguir con ella mayores luces para el mejor gobierno y prudencia del modo curatibo con arreglo a sus doctrinas que a su parece ban fundadas las reglas medicas y para su logro con la mayor brevedad otorga que de todo su poder cumplido quan bastante por derecho se requiere y es necesario para valer a don Antonio Massip y a don Salbador Pujal vecinos y residentes en la Corte de Madrid a ambos juntos y a cada uno de por si insolidum especial para que puedan parecer y de echo parezcan ante Su Majestad que Dios guarde y en el Consejo y Tribunal que corresponda de la dicha villa de Madrid y demas superiores que sean necesarios y pidan se facilite la impresión del citado libro intitulado Apologemas (sic) de la mas verosimil Medicina // a cuio fin y hasta que lo consiga e impetren las licencias necesarias en la forma regular haran el pedimiento o pedimientos convenientes y demas diligencias que para ello conbengan a el mejor éxito de esta pretensión, suplicas e instancias con presentacion de papeles necesarios y las mismas que el otorgante hacer podria por su persona presente siendo que el poder que para todo lo referido cosa y parte por derecho se requiere el mas especial ese mismo les da y otorga sin limitacion ni reserba de cosa a los referidos don Antonio Massip y don Salbador Pujar (sic) con incidencias y dependencias, anecsidades y concecsidades (sic) libre yo franca y general administración relebacion y obligacion y con toda la amplitud y plenitud de clausulas que para obrar se requieran y con la expresa de enjuiciar jurar y que lo puedan subtituir en quien quisieren rebocar substitutos (sic) y crear otros de nuevo y asi lo dijo otorgó y firmó siendo testigos Manuel Sánchez Tarazada, Pedro Martinez Cavallero y Bartolomé Brabo vecinos desta villa.

Don Joseph Pares (rúbrica) Ante mi Juan Perez Escobar-derechos 3 reales-

Documento 4.- Desposorio de $D^{a}$ Antonia Parés y Franqués con D. Francisco de la Garza (feb. 1791)

En la villa del Almaden en quatro de febrero de mil settecientos nobenta y cinco, yo el licdo. Frey D. Joseph Calderon Lasso del havito de Calatrava, prior y cura recttor de la Yglesia Parroquial de Nra. Sra de la Estrella de esta villa del Almadén, por des- 
pacho del sr. D. Juan Fernandez de Alfonso y Gandira, visitador vicario y juez ecc ${ }^{\circ}$ de la ciudad de Ciudad Real y su partido en que dispensa de tres canonicas moniciones que manda el Sto. Concilio de Trento y sinodales de este arzobispado, haviendoles examinado de doctrina verdadera y constándome las licencias de sus maiores según el orden real, despose, unfacie, celesie por palabras de presente que hacen verdadero y lexitimo matrimonio a D. Francisco Carlos de la Garza y Cortés, natural del lugar de Valdenoceda, hijo lexitimo de D. Francisco y de $\mathrm{D}^{\mathrm{a}}$ Y sidora Martínez con $\mathrm{D}^{\mathrm{a}}$ Anttonia Parés y Franqués, natural de esta villa, hija lexitima de D. Josef y $\mathrm{D}^{\mathrm{a}}$ Juana Maria Ramiro Arcaios, siendo testigos Don Josef de Resa, presbítero; D. Francisco Losada y D. Jacinto Valiente; y lo firme:

Lizdo. Frey D. Josef Calderon Lasso.

Documento 5.- Capitulación, trato y obligación con el médico D. Juan Gomez del Barrio (octubre de 1769)

En la villa del Almaden en ocho días del mes de octubre de mil setecientos sesenta nuebe años, estando juntos en forma de cabildo como lo acostumbran los sres. D Joseph Garcia Recio Contador por S. M., theniente de Governador de esta villa, de su partido y administrador xeneral de sus R. Minas por ausencia y subdelegación de su señoria, Don Francisco y Don Juan Ramiro Arcayos, D Juan de Velasco Alarcon, Don Juan Salbago y Delgado, rexidores, D Julian Delgado, diputado y D. Francisco Antonio Lozano, sindico procurador para tratar y conferir las cosas tocantes al bien y procomún de este cabildo, por ante mi el escribano, dixeron que en atención a que D. Blas Barbera medico titular que hera de esta villa se a rremobido a la de Pozoblanco y a que D, Juan Gomez del Barrrio, que lo hera de la de Agudo a querido entrar en la vacante de dicho Blas y a bien presentado ante dichos señores para tratar ajustar y capitular su asistencia en esta villa y propuesto el partido que se le hace al referido para que sirva de medico titular en ella, conferenciado y controversiado este particular entre dichos señores y el expresado D. Juan se an convenido y ajuntado el que el referido // D. Juan Gomez asista a esta villa y su bezindario como tal medico titular de ella en la forma y condiciones siguientes.

$1^{\text {a }}$ Es trato y condizion que a de asistir en esta villa y sus vecinos del dicho D. Juan, como medico titular de hella por da principio mañana nuebe del corriente mes de octubre y cumplir otro tal dia del año que viene de mil setecientos setenta. Haciendo dos visitas a cada enfermo al dia y por cada una se le a de pagar por los pacientes un rreal de vellón.

$2^{\mathrm{a}} \mathrm{Ydem}$ es condición que a de visitar sin interés y gratuitamente como es practica a los srs. de este ayuntamiento: como son su señoria el señor Governador o en su lugar a su señoria su theniente, los quatro sres. rexidores, procurador sindico, escribano de dicho ayuntamiento y contador de propios, practicando las visitas correspondientes a dichos sres. y en la misma manera a sus familias, esto siempre que haya necesidad con la precisa obligación de que a de asistir, aunque concurra otro medico pues no por eso se a de escusar. 
$3^{\text {a }}$ Que por la espresada asistencia a este vecindario se le an de pagar en cada un año de los que sirba tres mil y trescientos rs. de vn. Por este villa satisfechos por tercios de sus propios y arbitrios según se // acuerda y convenga.

$4^{\text {a }}$ Ytem es condicion que si cumplido el tiempo de esta contrata no conveniese a dicho D. Juan la continuidad en esta villa, ni a sus mercedes los sres. del Ayuntamiento que prosiga por mas tiempo a de ser de la obligación respectiva de cada parte avisar dos meses antes de cumplir esta escritura para probeherse esta villa de medico y dicho D. Juan de partido, pero si por una ni otra no se cumpliese a tiempo señalado con esta condizion a de ser bisto continuar el año siguiente.

$5^{\text {a }}$ Yt. es condizion que en el caso que no aya enfermedad de cuidado y precediendo licencia de su señoria o su theniente aya de poder salir por apelación donde se le avise, con tal que no exzeda de veinte y quatro horas, o con espresion del caso y urgencia quedando providencia obtenga permiso para algún tiempo, pero siempre limitado por lo que pueda acaecer.

$6^{\mathrm{a}} \mathrm{Y}$ con estas condiciones y circunstancias de contrata se an convenido dichos sres. con el citado D. Juan obligando al cumplimiento de esta contrata los vienes propios y rentas de esta villa y especial sumisión a los sres. jueces y tribunales que de esta causa devan conocer por lo que respecta del ayuntamiento de esta villa y al dicho D. Juan Gomez del Barrio aceptaron este convenio y sus condiciones se obligan a cumplirlas en todo y por todo so espresa obligazion que hace.

Documento 6.- Partida de defunción de D. Joseph Parés y Franqués (octubre 1798)

En el Campo Santo del Real Hospital de esta villa del Almadén, en quatro de octubre de mil setecientos noventa y ocho, se enterró a D. Josef Parés y Franqués, marido que fue de $\mathrm{D}^{\mathrm{a}}$ Juana Ramiro, recibió el Santo Sacramento de la Extremaunción y otorgo testamento ante D. Juan López Arcayos, escribano, por el qual manda entierro ordinario con misa de cuerpo presente, vigilia y misa en la parroquial de esta villa, asistencia de doze religiosos a su entierro con limosna de dos rs. cada uno, a las mandas forzosas lo acostumbrado. Albaceas a Don Antonio Astorga, cura theniente de dicha parroquial y a D. Pedro Resa y herederos a sus dos hijas Da Antonia y D Luciana Parés, y lo firme: Astorga. 


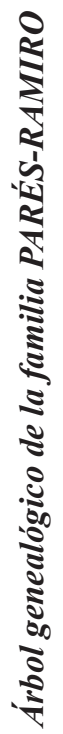

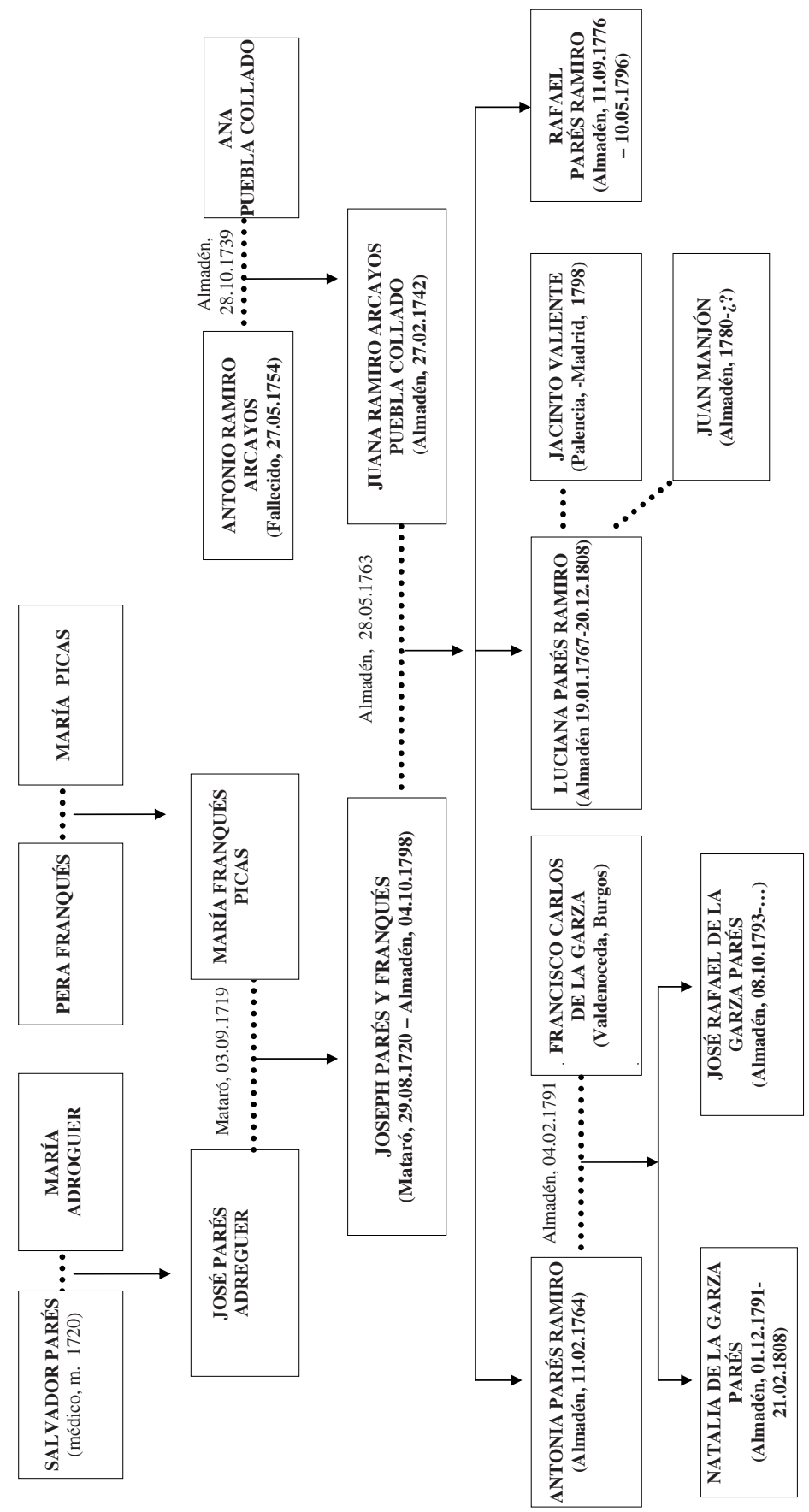

